\title{
Treatment of Feline Mammary Fibroepithelial Hyperplasia Following a Single Injection of Proligestone
}

\author{
R. VITÁSEK, H. DENDISOVÁ
}

Small Animal Clinic, University of Veterinary and Pharmaceutical Sciences, Brno, Czech Republic

Received November 25, 2005

Accepted March 16, 2006

\begin{abstract}
Vitásek R., H. Dendisová: Treatment of Feline Mammary Fibroepithelial Hyperplasia Following a Single Injection of Proligestone. Acta Vet. Brno 2006, 75: 295-297.

A case of fibroepithelial hyperplasia of the mammary gland in the cat is reported. A seven-monthold female cat was presented for diffuse enlargement of all of the mammary glands. The cat was treated with proligestone $\left(\right.$ Covinan ${ }^{\circledR}$ ) for the suppression of estrus. Four weeks later all 8 mammary glands were asymmetrically enlarged. There was ulceration of one gland. Sonographic imaging of the affected mammary glands showed homogeneous and granular structures. The patient was treated with subcutaneous injections of $10 \mathrm{mg} / \mathrm{kg}$ aglépristone (Alizine ${ }^{\circledR}$ ) on days 1, 2, 7, 14 and 21. Within six weeks the mammary glands had completely regressed. No side effects were observed. It is the first case of fully documented feline mammary fibroepithelial hyperplasia and its treatment in the Czech Republic.
\end{abstract}

Queen, progestin, antiprogestin, progesteron

Feline mammary fibroepithelial hyperplasia is a growth disturbance of cats characterised by rapid, non-neoplastic proliferation of ductal epithelium and stroma of the mammary gland resulting in enlargement of one, several or all of the mammary glands (Allen 1973). Other terms for the same condition can by found in literature, including feline mammary hypertrophy, feline mammary fibroadenomatosis and fibroadenoma (Nimmo and Plummer 1981).

The condition occurs spontaneously in young, sexually intact queens at the time of puberty, during the first oestral cycle, pregnancy or pseudopregnancy and may regress spontaneously or require ovariectomy. Feline mammary fibroepithelial hyperplasia can be induced by administration of progesterone-containing compounds including synthetic progestins such as megestrol acetate and medroxyprogesterone acetate (Hayden et al. 1989; Gorlinger et al. 2002; MacDougall 2003; Loretti et al. 2004).

In most cases, fibroepithelial hyperplasia can by diagnosed based on typical clinical findings such as diffuse, firm swelling of one or more glands without signs of inflammation (Wehrend et al. 2001).

The purpose of the present study is to report the symptoms, history, clinical and ultrasound findings and treatment of a cat that developed mammary fibroepithelial hyperplasia after a single injection of proligestone.

\section{Materials and Methods}

History, examination and therapy

A seven-month-old female cat (Maine Coon) was presented with diffuse enlargement of all of the mammary glands. Two months earlier $0.75 \mathrm{ml}$ pro toto proligestone (Covinan ${ }^{\circledR}$, Intervet) had been used for prevention of oestrus. The owner found out enlargement of all mammary glands four weeks after injection of proligestone. At inspection and palpation, the cat had oedematous and distinct asymmetrical enlargement of all 8 mammary glands, with diameters ranging from 10 to $12 \mathrm{~cm}$ (Plate XIII, Fig. 1). There was ulceration of one gland. At clinical examination, body temperature, respiration and heart rates were normal. The cat was lethargic and anorectic. Sonographic imaging of the affected mammary glands showed characteristic homogeneous and granular structures (Plate XIII, Fig. 2). 
Differential diagnoses included mammary adenocarcinoma or carcinoma, mammary adenoma, or mammary sarcoma or mastitis. Due to the recent history of progestin administration and the involvement of more than 1 gland, mammary hyperplasia was the most likely diagnosis. Patient was treated with subcutaneous injections of $10 \mathrm{mg} / \mathrm{kg}$ aglépristone (Alizine ${ }^{\circledR}$, Virbac) on days $1,2,7,14$ and 21.

The length, width and height of glands were measured. We calculated the content of the mammary gland $(\mathrm{V}=1 \times \mathrm{w} \times \mathrm{h})$.

\section{Results}

Starting approximately five days after the first injection, a significant reduction in the size of the mammary tissue was seen (Table 1), accompanied by a change of tissue consistency from rigid to elastic to soft. Within six weeks the mammary glands had completely regressed. No side effects were observed.

Table1. Feline mammary fibroepithelial hyperplasia - weight of cat and size of mammary during therapy

\begin{tabular}{|c|c|c|}
\hline Control (day) & Weight of the cat $(\mathrm{kg})$ & Contents of the mammary gland $\left(\mathrm{cm}^{3}\right)$ \\
\hline 1 & 4.2 & 2040 \\
\hline 7 & 3.6 & 840 \\
\hline 14 & 3.8 & 400 \\
\hline 21 & 3.8 & 180 \\
\hline 28 & 3.9 & 50 \\
\hline
\end{tabular}

\section{Discussion}

Immunohistochemistry performed on hyperplastic mammary glands detected progesterone receptors in the nuclei of ductal cells, and growth hormone and insulin-like growth factor-I in the cytoplasm of ductal epithelium with no oestrogen receptors detected (Loretti et al. 2004).

Martín de las Mulas et al. (2000) detected progesterone receptors in epithelial cells or in epithelial and stromal cells, oestrogen receptors were detected in approximately half of the cases. Local production of growth hormone $(\mathrm{GH})$ and insulin-like growth factor enhances the proliferation of the mammary tissue in an autocrine and/or paracrine manner, and mammary epithelial cells are capable of producing GH locally under adequate progesterone stimulus (V an Garderen et al. 1997). Progestin-induced local synthesis of growth hormone and insulin-like growth factor in mammary epithelial cells has been proposed as an additional pathogenic mechanism involved in the development of feline mammary fibroepithelial hyperplasia (Mol et al. 1996). In progestin-treated cats mammary fibroepithelial hyperplasia is associated with local GH expression (Mol et al. 1996).

Due to its progesterone dependency, the hyperplasia can by treated by elimination of the source of progestin. Common therapy of feline mammary fibroepithelial hyperplasia is ovariohysterectomy or mastectomy (Hoffmann and Schuler 2000). Thus, until recently, ovariectomy was considered the treatment of choice, leading to regression of the mammary tissue within three to four weeks.

As an alternative treatment, administration of antiprogestins was introduced by Blendinger et al. (1994). The therapeutic mechanism is based on an antagonism to the action of progesterone at its intracellular receptor (Elger and Chaw alis z 1999) and, thus, inhibition of its growth stimulating effect. Feline mammary fibroepithelial hyperplasia was treated with the progesterone antagonist aglepristone by Wehrend et al. (2001), Gorlinger et al. (2002), Meisl et al. (2003), Nak et al. (2004). In cases of fibroepithelial hyperplasia which developed after administration of depot progestin, a repeated or prolonged antiprogestin treatment was required until the effects of exogenous progestins subsided. The mammary glands had regressed to normal within 3 to 11 weeks. 
In conclusion, the treatment of feline mammary fibroepithelial hyperplasia with antiprogestin has proven to be a valuable, well-tolerated and effective therapy.

\section{Léčba fibroepiteliální hyperplazie mléčné žlázy u kočky vzniklé po jednorázové aplikaci proligestonu}

V této kazuistice je popsán př́ípad sedmiměsíční kočky (Mainská mývalí) s fibroepiteliální hyperplazií mléčné žlázy. Příčinou tohoto stavu bylo jednorázové podání proligestonu $\left(\right.$ Covinan $\left.{ }^{\circledR}\right)$ za účelem suprese estru. Za čtyři týdny po této aplikaci došlo k asymetrickému zduření všech osmi mléčných oddílůn, na jednom mléčném oddíle byla ulcerace. Při ultrasonografickém vyšetření byla zjištěna homogenní struktura postižené mléčné žlázy. Kočce bylo subkutánně aplikováno $10 \mathrm{mg} / \mathrm{kg}$ aglépristonu (Alizine ${ }^{\circledR}$ ) a to 1., 2., 7., 14. a 21. den. Během šesti týdnů došlo ke kompletní regresi mléčné žlázy. Nebyly zjištěny žádné vedlejší účinky léčby.

\section{References}

ALLEN HL 1973: Feline mammary hypertrophy. Vet. Pathol 10: 501-508

BLENDINGER K, BOSTEDT H, HOFFMANN B 1994: Induction of abortion and medical-treatment of fibroadenomatosis in a cat using the antigestagen Ru-46534. Kleintierpraxis 39: 495-499

ELGER W, CHAWALISZ 1999: Antagonists for gynecological therapy. Reproduktionsmedizin 15: 318-335

GORLINGER S, KOOISTRA HS, VAN DEN BROEK A, OKKENS AC 2002: Treatment of fibroadenomatous hyperplasia in cats with aglepristone. J Vet Internal Med 16: 710-713

HAYDEN DW, BARNES DM, JOHNSON KH 1989: Morphologic changes in the mammary-gland of megestrol acetate-treated and untreated cats: a retrospective study. Vet Pathol 26: 104-113

HOFFMANN B, SCHULER G 2000: Receptor blockers - general aspects with respect to their use in domestic animal reproduction. Anim Reprod Sci 60: 295-312

LORETTI AP, IIHA MRS, ORDÁS J, DE LAS MULAS JM 2004: Clinical, pathological and immunohistochemical study of feline mammary fibroepithelial hyperplasia following a single injection of depot medroxyprogesterone acetate. J Feline Med Surg 7: 43-52

MACDOUGALL LD 2003: Mammary fibroadenomatous hyperplasia in a young cat attributed to treatment with megestrol acetate. Canad Vet J 44: 227-229

MARTÍN DE LAS MULAS J, MILLÁN Y, BAUTISTA MJ, PÉREZ J, CARRASCO L 2000: Oestrogen and progesterone receptors in feline fibroadenomatous change: an immunohistochemical study. Res Vet Sci $\mathbf{6 8}$ : 15-21

MEISL D, HUBLER M, ARNOLD S 2003: Der Progesteronantagonist Aglépristone (Alizine (R)) zur Behandlung der Fibroepithelialen Hyperplasie der Mamma bei der Katze. Schweiz Arch Tierh 145: 130-136

MOL JA, VAN GARDEREN E, RUTTEMAN GR, RIJNBERK A 1996: New insights in the molecular mechanism of progestin-induced proliferation of mammary epithelium: Induction of the local biosynthesis of growth hormone $(\mathrm{GH})$ in the mammary gland of dogs, cats and humans. J Steroid Biochem Mol Biol 57: 67-71

NAK D, NAK Y, SEYREK-INTAS K, KUMRU IH 2004: Treatment of feline mammary fibroadenomatous hyperplasia with aglepristone. Aust Vet Pract 34: 161-162

NIMMO JS, PLUMME, JM 1981: Ultrastructural studies of fibroadenomatous hyperplasia of mammary glands of 2 cats. J Comp Pathol 91: 41-50

VAN GARDEREN E, DEWIT M, VOORHOUT WF, RUTTEMAN GR, MOL JA, NEDERBRAGT H, MISDORP W 1997: Expression of growth hormone in canine mammary tissue and mammary tumors - Evidence for a potential autocrine/paracrine stimulatory loop. Amer J Pathol 150: 1037-1047

WEHREND A, HOSPES R, GRUBER AD 2001: Treatment of feline mammary fibroadenomatous hyperplasia with a progesterone-antagonist. Vet Rec 148: 346-347 
Plate XIII

Vitásek R. et al.: Treatment of feline ... pp. 295-297

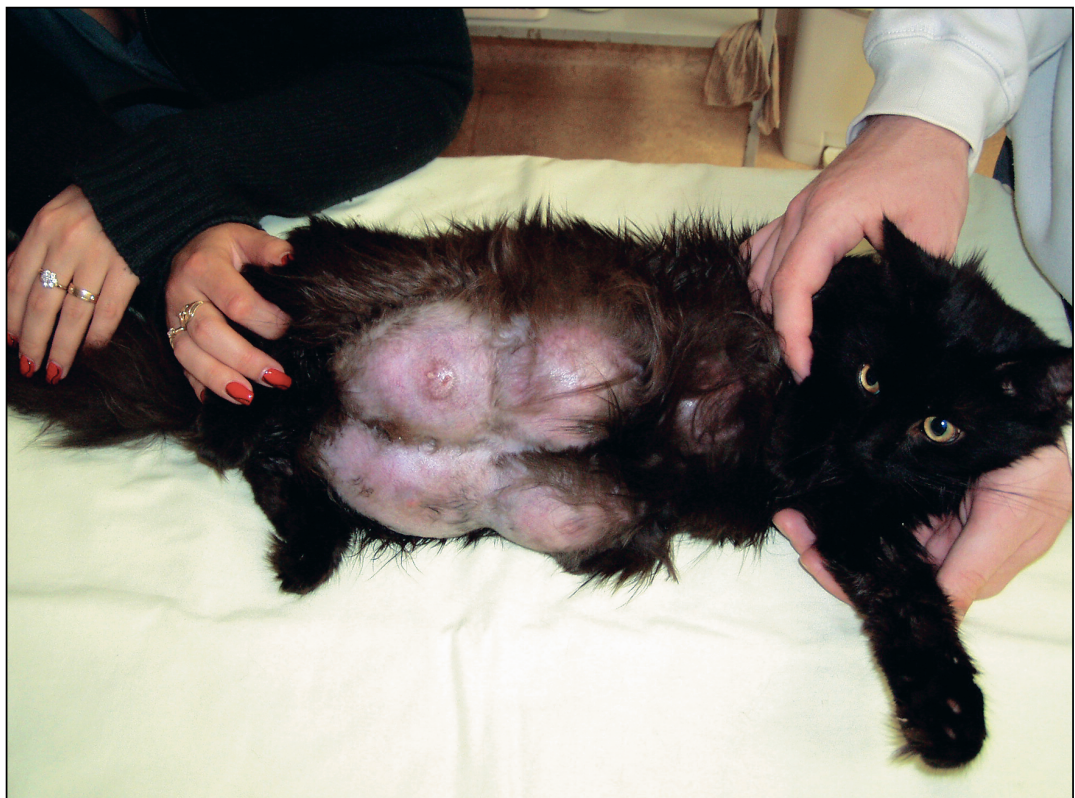

Fig.1. A seven-month-old female cat (Maine Coon) with a typical feline mammary fibroepithelial hyperplasia

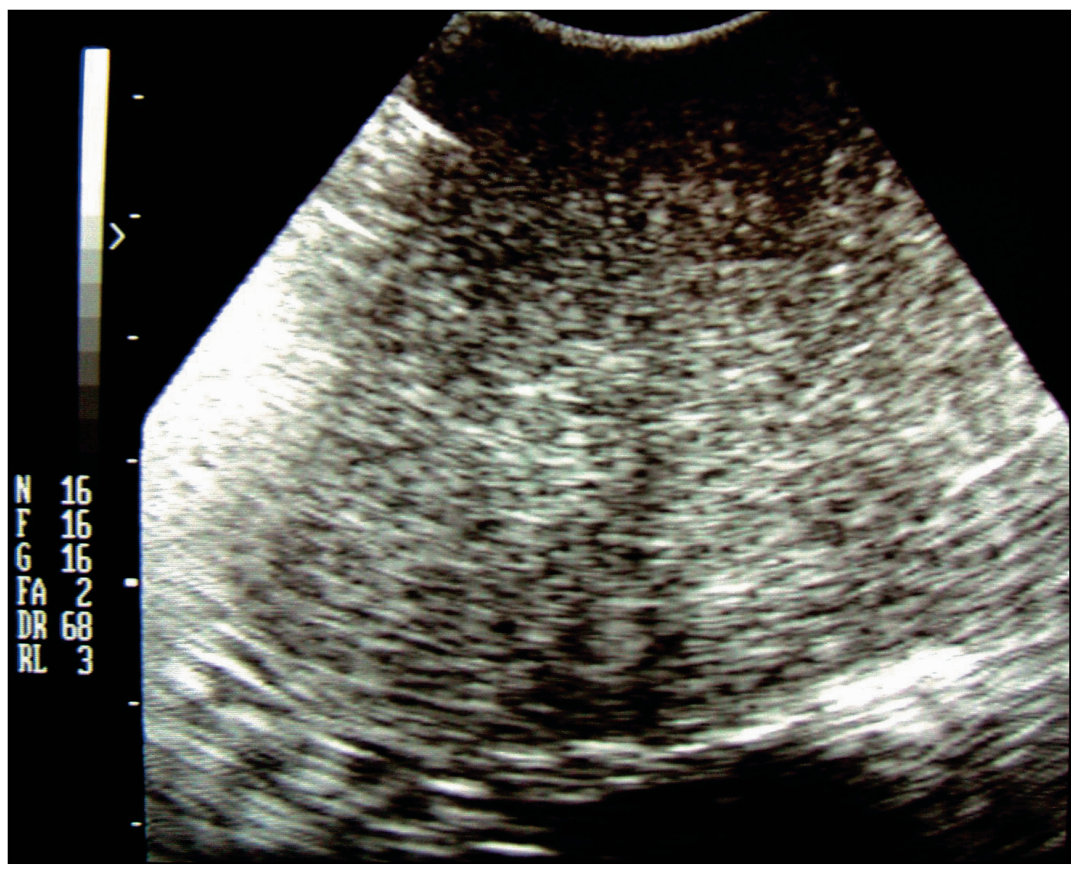

Fig. 2. Feline mammary fibroepithelial hyperplasia - the ultrasonographic image of the mammary tissue reveals a characteristic homogeneous structure (7 MHz scanner) 